\title{
Ecotourism and Sustainable Community Development: A Case Study of Sillery Gaon, West Bengal
}

\author{
Pranab Kr. Das \\ Assistant Professor, Department of Geography, Sree Chaitanya College, Habra, West Bengal, India
}

*Corresponding author: pranabtaki@gmail.com (ORCID ID: 0000-0002-6333-9509)

Received: $17-11-2020$

Revised: $18-02-2021$

Accepted: 05-03-2021

\begin{abstract}
Ecotourism has a significant role in community development in the host areas through alternative but sustainable livelihood. This tourism practice meets the needs of the tourists and hosts together, protecting the natural environment. Nowadays, this tourism involves visiting new areas to learn about various landscapes, environment, habitats as well as the cultural activities of an individual community. It also expands the possibilities for future. So, ecotourism can be an effective method for sustainable rural development in the Himalayan tract of West Bengal. In Darjeeling and Kalimpong districts of West Bengal, ecotourism is still a community-based activity which involves local people and their culture. Most of the ecotourism sites in this part of West Bengal are within forest and hilly tract. Here growth of ecotourism has been phenomenal during the last decades with the influx of tourists that boosted the local economy. Sillery Gaon, a small village, in 'Silk Route Circuit' of West Bengal, is a new addition to it and a perfect example of this scenario. It is situated in Kashyone, gram panchayat of Kalimpong District. This pictorial village is surrounded with the dense forest of Pankhasari range and blessed with the panoramic view of Tista River and Kanchenjunga. In the last ten years, the villagers have developed ecotourism facilities and activities which transformed their traditional agrarian economy to tourismbased livelihood. This paper is based on a case study that analyses the symbiotic relationship between the ecotourism practice and sustainable community development of Sillary Gaon village. It also deals with the prospects and challenges of ecotourism sector of this village.
\end{abstract}

\section{Highlights}

(0 Ecotourism is an effective tool for sustainable community development at Silary Gaon.

(0 This tourism practice is very helpful in women empowerment and gender equality.

( Majority of the villagers are directly engaged with ecotourism and transforming their traditional occupation.

(0) The growth of ecotourism has been phenomenal at Silary Gaon since the last decades but facing severe infrastructural crisis.

Keywords: Ecotourism, Community Development, Rural Empowerment, Sustainable Livelihood, Sillery Gaon

In contemporary tourism industry 'Ecotourism' is a common term, used in public domain knowing or unknowing of its objectives and aspects. Still, there is no specific definition of it (Murugan, 2006). It has several meaning and concepts. There are exceptional market values of ecotourism which perhaps continue in future. It is usually considered as a sensible tourism practice.
The world Travel and Tourism Environment Research Centre in its 1993 World Travel and Environment Review defined ecotourism as "tourism with a specific

How to cite this article: Das, Kr. P. (2021). Ecotourism and Sustainable Community Development: A Case Study of Sillery Gaon, West Bengal. Int. J. Soc. Sci., 10(01): 21-28.

Source of Support: None; Conflict of Interest: None (क) 
motive of enjoying wildlife or underdeveloped natural areas" (Victor and Rebecca, 1993). The travel industry defines ecotourism as "purposeful travel that creates an understanding of cultural and natural history while safeguarding the integrity of the ecosystem and producing economic benefits that encourage conservation." (Bandy, 1996). The International Tourism Society defined Ecotourism as "a form of tourism involving visiting fragile, pristine, and relatively undisturbed natural areas, intended as a low-impact and often small scale alternative to standard commercial (mass) tourism." (Walpole et al. 2001) The purpose of ecotourism involves education of the travellers, to provide funds for ecological conservation, to directly benefit the economic development and empowerment of local communities. (Bassam and Rahman, 2016). Ecotourism programme includes the negative aspects of conventional tourism on the environment and enhances the cultural integrity of local people (Sing, 2015). However, it plays an important role in community empowerment in the host area and surroundings. In this context it may be defined as "a form of tourism that is responsible for the preservation of the natural area, provides economic benefits and maintains the cultural integrity of local communities (Deru and Nike, 2016).

Environment sustainability is very important for community empowerment in rural areas. At present context a new termed has been coined; 'Responsible Ecotourism' (Chiu et al. 2013). If ecotourism is practised responsibly it could be beneficial for both guest and host. So, the local communities could utilise the purity of their environment for livelihood. Considering these issues, Govt. of West Bengal passed West Bengal Tourism Policy in 2016 which encourages homestay facilities in different natural areas to enhance community development. Govt. of West Bengal is promoting different virgin tourist spots and circuits in the picturesque Himalayan tract of Darjeeling and Kalimpong districts as ecotourism destinations (West Bengal Tourism Policy, 2016). Local communities are also promoting their areas for homestay facilities with the wrapper of ecotourism. In this context, Sillery Gaon is a perfect example of this scenario. The present studies deal with the role of ecotourism in community development and sustainable livelihood of Sillery Gaon village emphasising on its prospects and problems.

\section{Objectives}

The present studies deals with the following objectives:

* To study the present tourism recourses and accommodation facilities of Sillery Gaon,

* To study the role of ecotourism in community development,

* To study the prospect and problems ecotourism at Sillery Gaon.

\section{Study Area}

Sillery Gaon $\left(27^{\circ} 8^{\prime} 22.40^{\prime \prime} \mathrm{N}, 88^{\circ} 34^{\prime} 49.39^{\prime \prime} \mathrm{E}\right)$ is a small village of Kashyone Gram Panchayat in Kalimpong District of West Bengal. This village is surrounded by the tropical mixed forest of Pankhasari range at an average elevation of $1790.83 \mathrm{~m}$. (5938.32 ft). Area of the village is only 6.81 hectares. It is $94 \mathrm{~km}$ away from New Jalpaiguri (NJP) and $23 \mathrm{Km}$ away from district headquarter, Kalimpong. The nearest census town is Algarah which is $12 \mathrm{~km}$ away from this forest village. Sillery Gaon is one of the favourite tourist destinations of Silk Route circuit.

This pectoral village blessed with natural beauty and an ideal destination for the nature lovers. Sillery Gaon, trekker's paradise, offers three short trek routes from here; Sillery Gaon - Ramitey View Point, Sillery GaonIcche Gaon and Sillery Gaon-Damsang Fort. The Ramitey viewpoint provides the magnificent view of the $\mathrm{Mt}$. Kanchenjunga above and the Teesta River below with its 14 meandering and the confluence point Rishi River, together. The Damsang Fort, last residence of the Lepcha King- Gyabo Achuk, was built in 1690. The Lepchas had lost the fort to the Bhutanese and then it was accessed by the British after the Anglo-Bhutan War of 1864 (Lepcha, 2017). Nothing much remains of Damsang Fort but history lovers can visit the place. One can also trek to Ichhe Gaon from this village within the virgin tropical mixed forest which may be an unforgettable experience.

'Sillery Gaon' derives its name from Cinchona plant that grows in abundance in this region. The British rulers introduced Cinchona Plantation in this region 
as a source of Quinine for the treatment of Malaria (Malley, 1907). After independence, this area remained a plantation circuit and forest area. This village was set up in the early 1970s by the migrant labourers of the forest department, mostly engaged in lumberjacking and cinchona plantation. They were from Mane Bhanjang, Kali Pokhari, Dhotrey, Okhery and Gorkhey (near to Nepal border) and belong to the Gorkha community (Chetri, 2013). The villagers were traditionally engaged in the plantation of cinchona, big cardamom and lumberjacking under forest department. Inspiring from nearby areas the villagers adopted eco-tourism at Sillery Gaon. In 2009 four friends, Dilip Tamang, Kaji Tamang, Biru Tamang, and Kamal Tamang stated ecotourism facilities herewith few cottages.

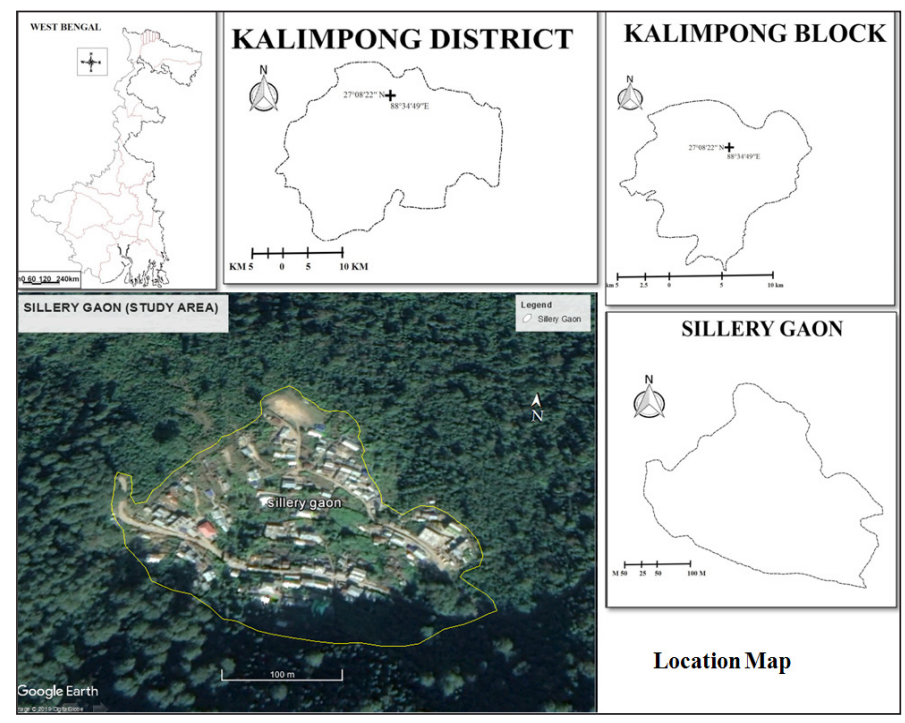

Fig. 1: Location map

Source: Author E Google Map

It is a tribal village inhabited by only 169 people of 32 families among them $52.66 \%(n=89)$ are males and $47.34 \%(n=80)$ are females. Majority of the villagers are Buddhist (78.5\%) followed by Hinduism (14.28\%) and Christianity (7.14\%). The villagers are mostly Tamang $(54.44 \%)$ rest belong to Rai $(10.65 \%)$, Bhujel $(8.24 \%)$, Thapa $(7.10 \%)$, Sherpa $(7.73 \%)$, Kami $(4.73 \%)$ and Damai $(4.14 \%)$ community. However, they commonly introduce themselves as Gorkha. Literacy rate of this village is $74.56 \%$. At present $56.25 \%$ household $(n=18)$ are actively operating homestay business.

\section{Database and Methodology}

The present paper deliberated as an intensive case study that involves the collection of both primary and secondary data. The field observation and investigations were conducted in two phases; during $29^{\text {th }}$ October to $31^{\text {st }}$ October 2018 during Puja Vacation (peak season), and $25^{\text {th }}$ November to $28^{\text {th }}$ November 2018, after Puja Vacation (lean season). During the field visits, the physical observation was made on community activities of Sillery Gaon village. 70 local people who engaged in ecotourism business and 14 homestays were surveyed through stratified random sampling with a standard set of questionnaire. Tourists, transport workers were also interviewed to understand various issues related to ecotourism at Sillery Gaon. Secondary data were collected from the register of the homestays, Kalimpong-2 Block Office and Dasmung Forest Bit office and KITAS (Kalimpong Institute of Tourism Association and Society). Collected data were compiled and analyzed through specific statistical methods. For the preparation of maps, Google Earth Pro and Q-GIS (version 2.8.1) were used.

\section{RESULTS}

\section{Profile of the Interviewees}

During the survey, a conscious effort was given for maintaining the balance between male and female respondents form various age groups for more impartial representation. Among the total respondents $(N=70), 45.71 \%(n=32)$ were male and $54.29 \%(n=38)$ female. The age of the respondents ranges from 16 to 65 years. Their average age was 34.73 years $(\sigma=12.684)$. Among the total $(N=70)$ respondents, $74.29 \%(n=52)$ were literate and rest $25.71 \%(n=18)$ were illiterate, the average level of education was $5^{\text {th }}$ standard $(\sigma=4.076)$.

\section{Homestays and Their Accommodation Capacity}

Sillery Gaon is a one of youngest ecotourism spot of Kalimpong District. In spite of this the villagers has developed significant infrastructures. Presently, 56.25\% of households $(n=18)$ have homestay facilities. During the field study, 14 such homestays were surveyed. 50\% $(n=7)$ of them were constructed in between 2009 and 
$2011,28.57 \%(n=4)$ came in action during 2012 to 2014, $14.29 \%(n=2)$ constructed in between 2015 to 2017 and rest $7.14 \%(n=1)$ constructed after 2017. There are 151 rooms and 412 beds available among the 14 surveyed homestays. There are averagely 10.78 rooms $(\sigma=8.648)$ and 29.43 beds/ homestay $(\sigma=25.083)$. Haven Valley homestay provides maximum accommodation with $23.84 \%(n=36)$ rooms and $21.84 \%(n=90)$ of beds among the surveyed home stays. There is positive relation $(r=$ 0.936 ) between number of rooms and beds.

Table 1: Association of total number of room and bed

\begin{tabular}{lllllll}
\hline $\begin{array}{l}\text { Sl. Name of the } \\
\text { No Home Stay }\end{array}$ & $\begin{array}{l}\text { No. of } \\
\text { Rooms }\end{array}$ & $\begin{array}{l}\text { \% of } \\
\text { Rooms } \\
(\mathbf{X})\end{array}$ & $\begin{array}{l}\text { No. } \\
\text { of } \\
\text { Beds }\end{array}$ & $\begin{array}{l}\text { \% of } \\
\text { Beds } \\
(\mathbf{Y})\end{array}$ & $\begin{array}{l}\text { Index of } \\
\text { dissimilarity } \\
\text { (D=X-Y) }\end{array}$ \\
\hline 1 & Banalata-1 & 12 & 7.95 & 30 & 7.28 & $0.67^{*}$ \\
2 & Alisha & 08 & 5.29 & 24 & 5.82 & -0.53 \\
3 & Pema & 05 & 3.31 & 18 & 4.37 & -1.06 \\
4 & Banalata-2 & 08 & 5.30 & 16 & 3.88 & $1.42^{*}$ \\
5 & Nirmala & 17 & 11.26 & 68 & 16.50 & -5.24 \\
6 & Arjastik & 08 & 5.30 & 34 & 8.25 & -2.95 \\
7 & Mountain & 18 & 11.92 & 56 & 13.59 & -1.67 \\
& View & & & & & \\
8 & Haven Valley & 36 & 23.84 & 90 & 21.84 & $2.00^{*}$ \\
9 & Himalaya & 07 & 4.64 & 14 & 3.40 & $1.24^{*}$ \\
10 & New Banalata & 03 & 1.99 & 06 & 1.46 & $0.53^{*}$ \\
11 & Salina & 02 & 1.32 & 04 & 0.97 & $0.35^{*}$ \\
12 & Retreat & 10 & 6.62 & 20 & 4.85 & $1.77^{*}$ \\
13 & Khaling-1 & 12 & 7.95 & 22 & 5.34 & $2.61^{*}$ \\
14 & Khaling-2 & 05 & 3.31 & 10 & 2.43 & $0.88^{*}$ \\
\hline \multicolumn{2}{l}{ Total } & $\mathbf{1 5 1}$ & $\mathbf{1 0 0}$ & $\mathbf{4 1 2}$ & $\mathbf{1 0 0}$ & \\
\hline
\end{tabular}

Index of dissimilarity (Summation of Positive Values ${ }^{*}$ ) $=11.47$

Index of Similarity

$-(100-11.47)=88.53$

The homestays those have low dissimilarity indexes; provide more bed in respect to rooms. These are comparatively cheap; often use extra beds during peak seasons and earning profit through maximum occupancy.

Bed potential map was produced by the gravity model to find out the areas where the concentration of bed/ accommodation is highest in Sillery Gaon. The bed potential map shows that maximum bed potential could found in the southern part of the village. Towards the north, the potentialities decrease. Few budget homestays are also situated here. This part of the village provides a more prominent view of majestic Kanchenjunga, so tourists mostly prefer to stay at this location.

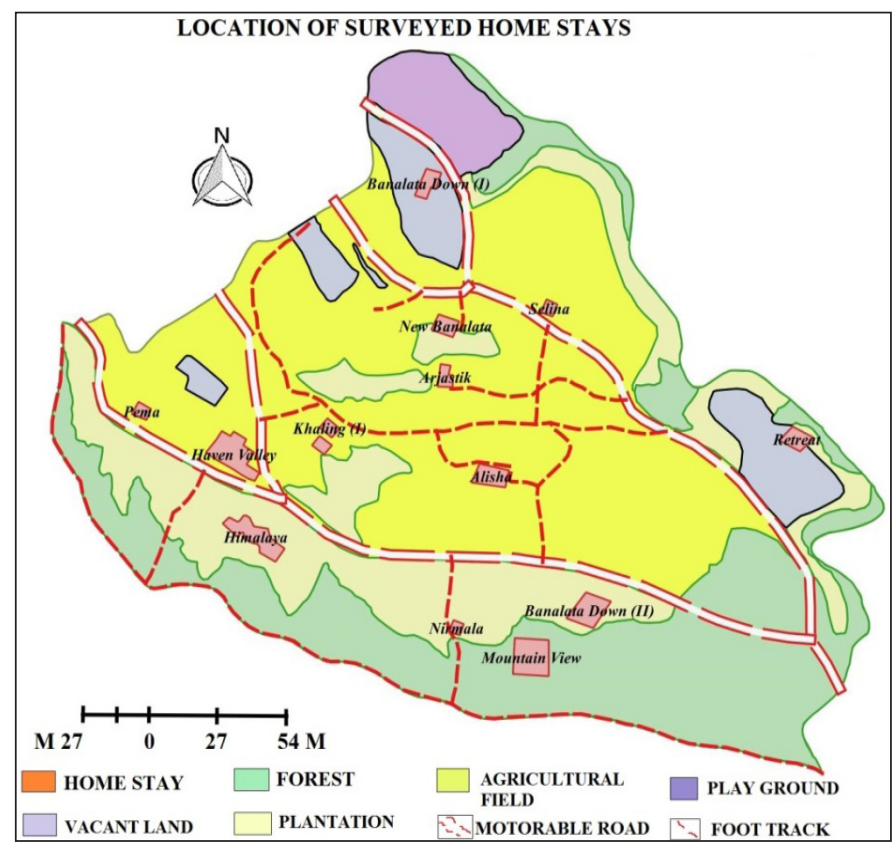

Fig. 2: Location of the surveyed home stays Source: Author

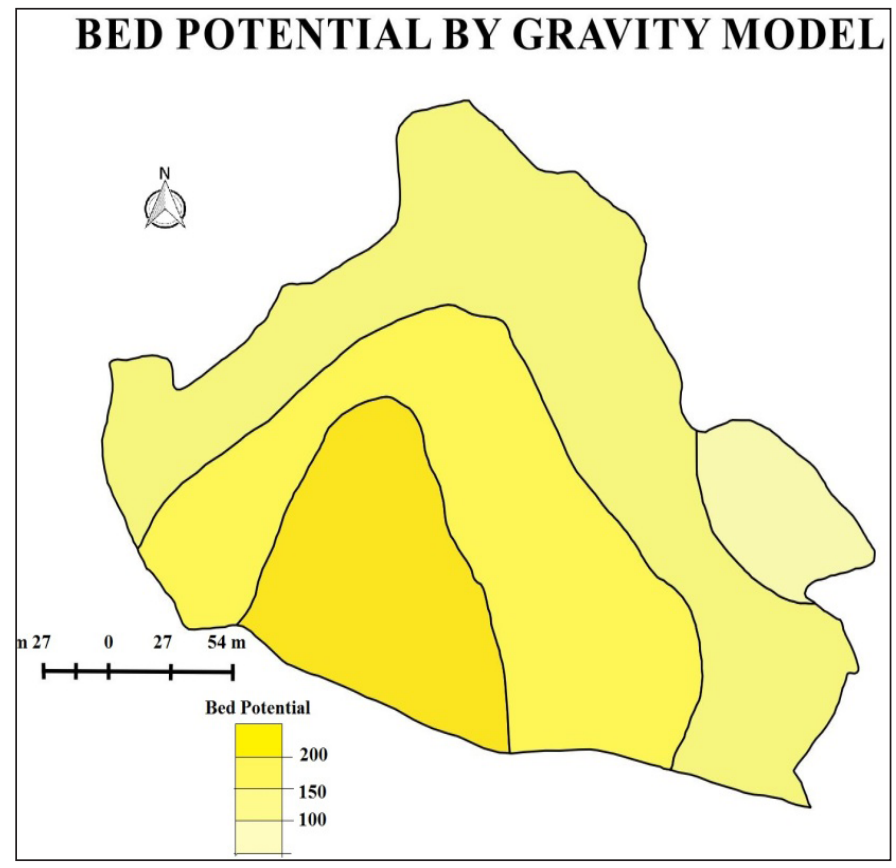

Fig. 3: Bed potential Source: Author 
Ecotourism and Sustainable Community Development: A Case Study of Sillery Gaon, West Bengal

\section{Tourist Flow and Income Generation}

Five years' data of visited tourists was collected from the register's home stays at Sillery Gaon. There is an increasing trend in tourist flow. Averagely 13.03\%/year growth rate has been noticed in term of tourist flow. The projected figure shows that in 2021 tourist visit can be increased up to $14.98 \%$ concerning to 2017.

Table 2: Tourist flow (from 2013 to 2017) and projected figure of 2021

\begin{tabular}{lllllll}
\hline Year & 2013 & 2014 & 2015 & 2016 & 2017 & $\begin{array}{l}\mathbf{2 0 2 1} \\
\text { (Projected) }\end{array}$ \\
\hline $\begin{array}{l}\text { No. of } \\
\text { Tourist }\end{array}$ & 33,965 & 35,967 & 40,272 & 49854 & 55,092 & 63,298 \\
$\begin{array}{l}\text { Growth } \\
\text { Rate }\end{array}$ & - & $5.89 \%$ & $11.97 \%$ & $23.79 \%$ & $10.50 \%$ & $14.98 \%$ \\
\hline
\end{tabular}

The average weekly income of the homestays was measured as per available data of 2017 from the surveyed homestays, considering peak and lean seasons. The average income of the homestays is ₹ $13460.71 /$ week ( $\sigma$ 7110.019) and profit ₹ 7221.43 ( $\sigma$ 3978.53). A positive correlation found $(r=0.974)$ between income and expenditure. It indicates that those are earning well also investing in their business. There is also a positive correlation $(r=0.86901)$ between the amount of bed and income. So, there is a prospect in ecotourism business in near future.

\section{Local Peoples' Attitude towards Eco-Tourism and Its Impact on Their Lifestyle}

$72.86 \%(n=51)$ of the villagers admitted that their lifestyle has improved and $78.57 \%(n=55)$ informed that their social interaction and exposures increased after the successful implementation of ecotourism. The villagers' attitude towards ecotourism had also been studied and found that the majority of them have a positive approach to it.
Table 3: Local peoples' response towards eco-tourism and its impact on their livelihood

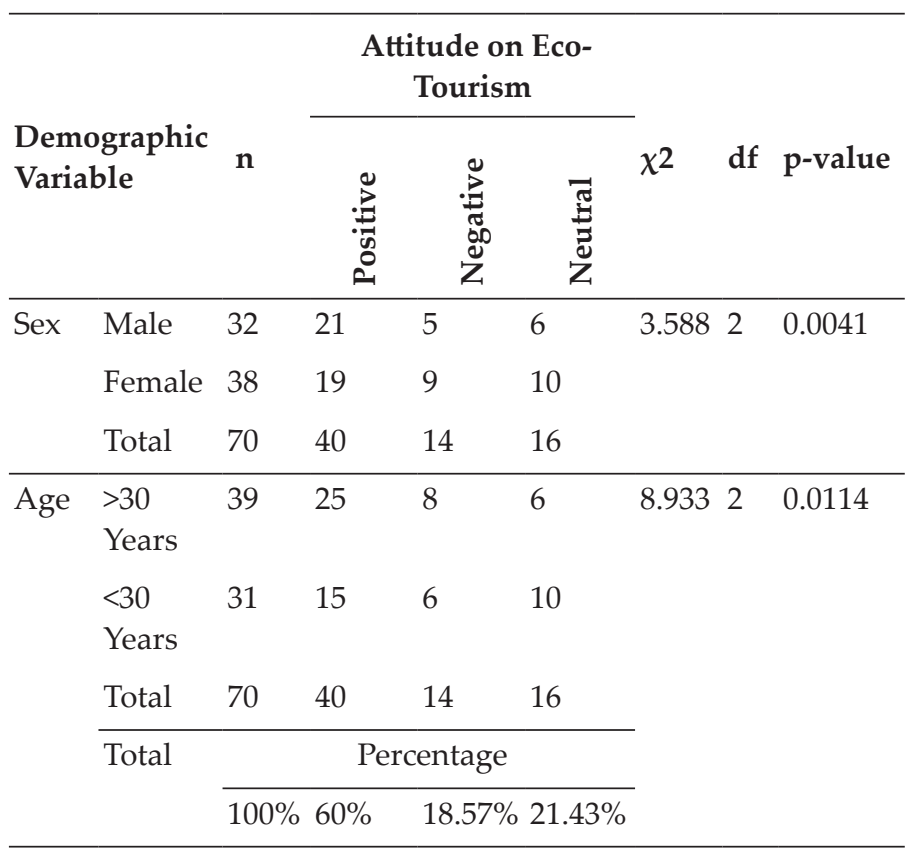

Source: Primary Data.

Overall it can be said that ecotourism is a profitable practice in Sillery Gaon and it has changed the life and livelihood of the villagers.

\section{Women Empowerment}

Among the total $(N=14)$ homestays $28.57 \%(n=4)$ are under the proprietorship of the female. It is an encouraging picture of women empowerment in such a remote village. Female participation rate in this sector is higher than the male. Among the total $(N=70)$ engaged persons in this hospitality business, $54.28 \%$ are female. Index of dissimilarity of female workers in this occupation is only 11.29. There is a positive correlation $(r=0.883)$ between total family members and female members engaged in homestays. It indicates female are more associated with this occupation. It was noticed that females are mostly engaged in six different types of work (Table 4). Even females calculate daily expense, expenditure and maintaining the accounts. It indicates women are in favourable conditions to take care, promote and operate their family businesses. 
Table 4: Section rating of female work participation

\begin{tabular}{|c|c|c|c|c|c|c|}
\hline $\begin{array}{l}\text { Sl. } \\
\text { No. }\end{array}$ & Types of Work & $\begin{array}{l}\text { Number of } \\
\text { Respondent } \\
(\mathrm{X})\end{array}$ & $\begin{array}{l}\text { Maximum Rating } \\
\text { Value } \\
\text { (Y) }\end{array}$ & $\begin{array}{l}\text { Sum of } \\
\text { Weighted } \\
\text { (Z) }\end{array}$ & $\begin{array}{l}\text { Maximum } \\
\text { Weighted } \\
(\mathrm{XY}) \\
\end{array}$ & $\begin{array}{l}\text { Section Rating } \\
(\mathrm{Z} / \mathrm{XY}) \times \mathrm{Y}\end{array}$ \\
\hline 1 & Meal Preparation & \multirow{6}{*}{$N=38$} & \multirow{6}{*}{5} & 62 & 190 & 1.63 \\
\hline 2 & Reception & & & 55 & 190 & 1.44 \\
\hline 3 & Catering & & & 52 & 190 & 1.36 \\
\hline 4 & Account \& Billing & & & 47 & 190 & 1.24 \\
\hline 5 & House Keeping & & & 40 & 190 & 1.05 \\
\hline 6 & Tour Guide & & & 26 & 190 & 0.68 \\
\hline
\end{tabular}

Source: Primary Data.

\section{DISCUSSION}

Sillery Gaon is a new addition to the ecotourism map of West Bengal. Now it is one of the favourite tourist destinations of Silk Route circuit. Here growth of ecotourism has been phenomenal during the last decades. The local economy has been boosted with the influx of tourists. Majority (56.25\%) of the villagers are directly engaged with this occupation. Villagers are transforming their traditional occupation (lumber jacking and plantation) towards ecotourism and allied professions. At present benefit of ecotourism directly or indirectly has reached in every family. Income and porches capacity both have increased. Previously, the villagers used to migrate seasonally to other parts of Darjeeling district and even in outsides. Now they generate jobs for others. A few numbers of Bengali workers from plains are working in the homestays. Villagers are also haring labours for construction, maintenances and plantation. Now women are more empowered as they are the main driving force of this hospitality business. They have become entrepreneurs and can take decisions within their families and communities. Ecotourism is still a community-based activity at Sillery Gaon, which involves local people and their culture. The villagers have made collective effort to promote sustainable eco-tourism in their communities for better livelihood. Here the ecotourism units are regulated by 'Sillery Villager's Association' formed by the local villagers. This association takes dissensions with the concern of its members regarding the tariff, maintenance of the main road, garbage disposable, general rules and regulations for the guests etc. Villagers' attitudes towards the environment and wildlife have significantly improved. They have realized that purity of nature is the key factors to promote their village in ecotourism arena. So, all the villagers are very conscious about the environment, health and hygiene. In this regard they take some collective measures; for example arrangement of garbage bins, segregation of solid and degradable waste, continuous monitoring on cleanses activities etc. Villagers have acknowledged that after the initiation of ecotourism the forest has become denser and beautiful. There are some issues which hamper the eco-tourism practice in Sillery Gaon.

Majority of the villagers (71.42\%) complained about the $4.7 \mathrm{~km}$ long road that connects the Sillery Gaon with the Pedong- Rishi road through Damsung forest. This entire road is very rugged, has no asphalt cover, full of boulders and sharp bends. The villagers mentioned it as the main obstacle of tourism.

$57.14 \%$ of villagers are not satisfied with the water supply. Previously water used to collect from a Jhora (spring) at the southern tip of the slope. It has dried up. Now water is collected from the northern end of the village (downward slope) where a break of the slope occurred $\left(42^{\circ}\right.$ to $23^{\circ}$ approx) within the dense forest. $2.5 \mathrm{~cm}$ diameter hard PVC pipes are inserted within the soft unconfined aquifer and 1 horse power water pumps are fixed at the other end of the pipe. A single pump can't pull water. Thus the similar type of pumps (as a booster) is attached at a regular interval with the same pipe to pull the water upwards homestays/household. The homestays use averagely 3 such pumps to collect 
water. During peak seasons water scarcity becomes a major issue here.

$\square 71.42 \%$ vilagers complained about poor coverage of mobile phone network. Only few pockets of the village are capable for optimum mobile signals. $4 \mathrm{G}$ network is not available. 3G service also fluctuates; only $2 \mathrm{G}$ connections are in working condition. So, the online booking, website, WiFi are very rare in Sillery Gaon.

$28.57 \%$ of villagers are not satisfied with the power supply, they complained about low voltage. $42.85 \%$ of villagers complained about non-availability of amusement facilities.

Majority of the tourists are not concerned about the concept of ecotourism. In the name of ecotourism, they are practising mass tourism. Tourists often demand urban facilities from the ecotourism units. This attitude of the tourists is not admissible. Hence the villagers are indulging them only to promote their business.

\section{CONCLUSION}

Ecotourism is an effective tool for sustainable development in rural areas of Darjeeling Himalaya. It meets the needs of the tourists and hosts together, protecting the natural environment. It plays a significant role in community development and women empowerment at Sillery Gaon through sustainable livelihood. Since the last decade, the villagers have developing ecotourism facilities which transformed their traditional agrarian economy. Nowadays, Sillery Gaon is one of best ecotourism destination of 'Silk Route Circuit'. Except for monsoon all round the year tourists are visiting here. Due to the influx of tourist, stress may come on the environment and wildlife. It may accelerate deforestation, soil erosion, ecological imbalance, instability of slopes etc. So, few initiatives may be taken for the improvement the tourism facilities as well as the environment.

The $4.7 \mathrm{~km}$ stretched road that connects Sillery Gaon with Pedong - Rishi Road through Damsung forest must be repaired immediately.
A new road can be constructed from Sillery Gaon to Bhalu Marg Road via Icche Gaon that will decrease travel time from Kalimpong.

$\square$ Gorkha Territorial Administration (GTA) is laying a water pipeline from the north end of Sillery Gaon to a newly constructed bull farm at Pedong $(12 \mathrm{~km}$ away) avoiding Sillery Gaon. This village can be part of this project. With the installation of $800 \mathrm{~m}$ aditional pipeline, the people of this village can get water very easily from their own territory.

$\square$ The $4 \mathrm{G}$ mobile towers can be installed in and around the village, which will improve the connectivity and business opportunity.

$\square$ Most of the tourists are not aware about the purpose of ecotourism. So, a 'Nature Interpretation Centre' could be developed to aware tourists about conservation policies, tradition of Gorkha community and objectives of ecotourism.

\section{REFERENCES}

Bandy Joe. 1996. Managing the Other of Nature: Sustainability, Spectacle, and Global Regimes of Capital in Ecotourism. Pub. Cul., 8(2): 539-66.

Bassam, K. and Mujeeb Rahman, A.P. 2016. Social Impacts of Ecotourism in India, IJARIIE, 2(6): 308-313.

Chiu Yen-Ting Helena, Lee Wan-I and Chen Tsung-Hsiung. 2014. Environmentally responsible behaviour in ecotourism: Antecedents and implications, Tourism Management, 40: 321329

Deru R Indika and Nike Vonika. 2016. Rural tourism development using ecotourism as a model of community empowerment in Cireundeu indigenous village, Cimahi, West Java, Indonesia, International Conference of Integrated Microfinance Management, Atlantis Press, pp. 148-154.

Lepcha Rongnyoo. 2017. Role of Pano Gaeboo Achyok in the Construction of Lepcha Identity, A Dissertation Submitted To Sikkim University for Degree of Master of Philosophy, at Department of Anthropology School of Human Sciences.

Mona Chettri. 2013. Choosing the Gorkha: at the crossroads of class and ethnicity in the Darjeeling hills, Asian Ethnicity, 14(3): 293308.

Murugan Annamalai. 2006. Exploring the Potential and Usefulness of Ecotourism in Pondicherry with Special Reference to Tourism and Environment, Master plan and viable project report submitted to Department of Science, Technology \& Environment Govt. of Paducherry. 
Singh, V. 2015. Eco-Tourism as a Sutainable Alternative to Conventional Tourism, J. Tourism \& Hospitality, 4(4): 2.

Suharto Edi. 2010. Accommodating the urban Informal Sector in the Public Policy, New Zealand J. Asian Studies, 4(2): 115-133, 2003.

The International Ecotourism Society, "What is Ecotourism?" as available on www.ecotourism.org, accessed on 15.03.2020.
Victor T.C Middleton and Rebecca Hawkins. 1993. World Travel \& Tourism Environment Research Centre Oxford Brookes University, UK, The Tourist Review, 48(2): 10-13.

Walpole, M. and Goodwin, H. 2000. Local attitudes towards conservation and tourism around Komodo National Pak, Indonesia, Environ. Conserv., 28(2): 160-166. 